\title{
A REMUNERAÇÃO DO PROFESSOR É BAIXA OU ALTA? UMA CONTRAPOSIÇÃO DE DIFERENTES REFERENCIAIS
}

\author{
Amanda 0. Rabelo*
}

RESUMO: Este artigo debate a questão do estatuto financeiro e social da profissão docente, com base em uma revisão bibliográfica sobre o tema e relacionada aos dados empíricos de um estudo comparativo qualitativo e quantitativo que analisou questionários e entrevistas feitos com professores do sexo masculino que trabalham no ensino público primário do Rio de Janeiro-Brasil (RJ-BR) e em Aveiro-Portugal (AV-PT). A discussão bibliográfica teve como objetivo verificar se a consideração dos professores envolvidos sobre a remuneração da profissão tem alguma fundamentação. Tal estudo é importante porque a questão da remuneração da profissão é um dos aspectos que pode influenciar a escolha profissional, a satisfação com a docência, mas também que pode gerar insatisfação com o ofício. Foram encontradas grandes diferenças entre as respostas dos professores tanto do RJ-BR e de AVPT quanto dentro de cada localidade, o que mostra que os referenciais dos diferentes professores com relação ao salário do professor não são os mesmos.

Palavras-chave: Profissão Docente; Gênero; Remuneração; Estatuto Financeiro e Social, Professor do Sexo Masculino.

\section{IS REMUNERATION OF TEACHERS HIGH OR LOW?} \section{A COMPARISON FROM DIFFERENT BENCHMARKS}

ABSTRACT: This article discusses the financial and social status of teachers from a literature review on the topic and related to empirical data from a qualitative and quantitative comparative study that analyzed questionnaires and interviews carried out with male teachers working in public primary schools of Rio de Janeiro - Brasil (RJ-BR) and Aveiro - Portugal (AV-PT). The bibliographical review conducted aimed to examine whether the consideration of the involved teachers about their remuneration has some justification. This study is relevant as remuneration is one of the aspects that may influence the career choice and the satisfaction with the teaching profession, although it may also generate dissatisfaction. Great differences were found between the responses of male teachers from RJ-BR and AV-PT, as in each locality, which shows that salary referential of different teachers is not the same.

Keywords: Teaching profession; Gender; Remuneration; Financial and social status; Male teacher.

\footnotetext{
* Pós-doutoranda da Universidade de Coimbra; Doutora em Ciências da Educação pela Universidade de Aveiro; Pedagoga e Mestre em Memória Social e Documentos pela Universidade do Rio de Janeiro (UNIRIO), com Projeto de investigação financiado pela Fundação para Ciência e Tecnologia (FCT). E-mail: arabelo@ua.pt
} 


\section{Introdução}

O ponto de partida deste artigo foi uma investigação ${ }^{1}$ centrada na figura do professor do sexo masculino que trabalha no ensino público primário $^{2}$. Pretendia-se, fundamentalmente, averiguar os motivos e as consequências da escolha profissional desses professores que se enveredam por uma área tipicamente associada ao feminino. Tal investigação promoveu discussões centradas nas representações de gênero que rondam o campo profissional da docência, mostrando que existem indivíduos capazes de exercer a profissão por gosto e independentemente do seu sexo, mas que também sofrem com os problemas da docência.

Assinalamos que as representações associadas aos "atributos ditos femininos", assim como outros fatores, como o baixo estatuto financeiro e social, exercem/exerceram grande influência na escolha profissional dos entrevistados e inquiridos que se enveredam por tal área tão feminizada, dado que a porcentagem de professoras primárias é altíssima e a de professores primários, muito baixa.

Promovemos um estudo empírico que analisou as motivações para a escolha profissional dos professores do sexo masculino que trabalham no ensino primário público do Rio de Janeiro-Brasil (RJ-BR) e em Aveiro-Portugal (AV-PT), a partir de questionários e entrevistas que efetuamos com os mesmos ${ }^{3}$. Nesta apreciação, as justificativas presentes nos inquéritos demonstraram que a questão da remuneração da profissão docente é um dos aspectos que pode motivar (ou não) a escolha profissional, gerar satisfação profissional e pessoal, mas que, ainda mais, pode gerar insatisfação com o ofício.

Além disso, foram encontradas algumas diferenças entre as respostas dos professores tanto do RJ-BR e de AV-PT quanto dentro de cada localidade, o que nos fez questionar se, afinal, a remuneração do professor é baixa ou alta. Os professores que têm opiniões divergentes têm os mesmos referenciais com relação à remuneração docente? Existem diferenças nesses países? O que as motiva?

Para entender melhor tais dados e questões, este artigo apresenta uma revisão bibliográfica sobre a questão do estatuto financeiro e social da profissão docente em Portugal e no Brasil. Tal revisão é relacionada aos dados empíricos para analisar se as considerações sobre a remuneração docente dos professores participantes do estudo têm alguma fundamentação. 


\section{Salário do professor em Portugal}

Percebemos, com o suporte de vários autores, que, pelo menos até a Primeira República, os professores portugueses não recebiam bem; ao contrário, recebiam salários miseráveis ${ }^{4}$. Isso é observado pela seguinte afirmação de Mónica (1978, p. 188): "Ensinar os filhos dos pobres tem sido em toda a parte uma tarefa humilde desempenhada por pessoas humildes". Nóvoa (1991, p. 89) conta que os mestres de ler e escrever provinham das camadas mais baixas da sociedade, o que ajuda a perceber os baixos estipêndios que lhes eram concedidos. Era comum que os mestres dos séculos XVII e XVIII fossem homens com alguma moléstia ou enfermidade física, impossibilitados de trabalhar nos campos. Ou, então, eram artesãos, empregados ou mulheres que queriam algumas compensações suplementares.

Com a Reforma de 1772, a nomeação dos professores muda um pouco essa situação, mas os salários não têm melhoria significativa. Carvalho (1986, p. 456) descreve que, com a instituição do subsídio literário (e a necessidade de professores para suprir a expulsão dos jesuítas), o pagamento garantido era uma perspectiva de ganhar dinheiro que muitos aproveitaram - barbeiros, sapateiros, taberneiros, alcaides, escrivães que passaram a ser professores e mestres, muitas vezes juntamente com seus ofícios. Os salários eram, por vezes, irrisórios, com discriminações conforme se exercia a profissão em Lisboa ou em outra localidade.

Assim, de acordo com Nóvoa (1987), as políticas pombalinas favoreceram as regiões mais desenvolvidas e os professores secundários, em detrimento dos primários. De 1772 a 1794, os mestres régios de ler e escrever eram um grupo profissional muito mal-remunerado, que ganhava pelo menos duas vezes menos que os professores do secundário. Comparando com outros funcionários públicos de Lisboa, só os funcionários subalternos recebiam salários inferiores aos mestres régios, mesmo os "mestres" da construção recebiam mais do que os mestres régios (ao comparar o salário com o preço dos alimentos, conclui-se sobre a miserável condição econômica dos mestres régios). A remuneração miserável incitava a outras atividades, por isso, até o século XIX, os professores da instrução primária são obrigados a exercer outras atividades para não ficar na miséria ${ }^{5}$, só $50,4 \%$ exerciam somente o ensino 
primário, os outros trabalhavam no ensino privado, como escrivão, artesão, padre, comerciante, agricultor, profissional liberal e funcionário público.

A Reforma de 1878 ultrapassou a questão de as professoras receberem salário menor, apoiado pela lei', mas Araújo (2000, p. 93; 102103; 109) analisa que, como não havia, em Portugal, muitas reivindicações pela igualdade dos salários, "O salário igual para as professoras do nível primário foi introduzido possivelmente como forma de atrair mulheres para este trabalho". Os salários já eram baixos (miseráveis) e não aumentaram por um período de mais de trinta anos (professores reivindicavam que, para viver uma vida decente, o salário deveria ser o dobro), por isso a autora considera que atrair a força de trabalho feminina para o ensino associava-se com as expectativas sobre as mulheres de que seriam uma força de trabalho "compassiva", ou seja, que provavelmente não iriam queixar-se dos baixos salários. Dessa forma, as mulheres foram cada vez mais designadas a serem professoras primárias, num período em que os salários dos professores mantinham-se quase os mesmos.

$\mathrm{Na}$ segunda metade do século XIX, a criação das escolas normais, o desenvolvimento da formação escolar e a crença na virtude da instrução como fator de progresso transformam o acesso à profissão docente em aspiração de diferentes classes sociais e em via de promoção social; para Nóvoa (1987, p. 79) essa é uma época-chave para se compreender a ambiguidade do estatuto dos professores, pois o baixo salário não lhe permite um modo de vida típico de burguês: eles não são nem classe média nem classe popular. Nóvoa (1991, p. 93-94) refere que se assiste, então, à produção de um discurso que tende a "travar" a valorização do estatuto socioeconômico dos professores e a fixar a promoção da classe docente. Assim, na virada do século XIX, os professores de instrução primária constituem um grupo profissional em ascensão social, porém nem sempre há promoção econômica, mas promoção social e profissional. Cria-se a hierarquização e a ambiguidade entre salário e diploma: no nível econômico, o professor situa-se num escalão bastante baixo, mas o poder e o prestígio conferidos pela habilitação acadêmica situam o professor num escalão bem mais elevado.

Esse foi um tempo de crenças algo ingênuas e simplistas sobre o papel da escola e dos professores, no contexto de um Estado que paga um salário (miserável), recrutar, formar, isentar de impostos e dar 
reforma; porém, no seu estatuto, aparece o baixo estatuto econômico dos professores e sua condição de modestos funcionários públicos (instrumentos de manutenção e de reprodução). No entanto, "Não admira que os professores se sentissem bem com eles próprios e fossem capazes de minimizar algumas das insuficiências do seu estatuto económico e profissional, seguros como estavam da alta missão social que lhes era confiada" (NÓVOA, 1988, p. 11).

Já na I República, os professores tiveram algumas melhorias significativas. Em 1909, ganhavam o mesmo que operários de outras categorias; já em 191977, seus salários se situam ao mesmo nível que um tenente ou oficial de terceira categoria da administração; em 1935, são colocados ao mesmo nível dos sargentos ${ }^{8}$. Assim, Nóvoa demonstra que, nos anos de 1920, os professores de instrução primária atingem um estatuto econômico como nunca tinham possuído (e que só voltarão a deter meio século mais tarde) e que o período entre o fim da I Guerra e a implantação do Estado Novo constitui um momento em que os professores estavam relativamente satisfeitos com suas remunerações. A elevação dos salários repercute nas matrículas nas Escolas Normais de 1930 a 1936: 42\% dos inscritos nos cursos são do sexo masculino e 35\% dos formados de 1930-1938 são do sexo masculino (NÓVOA, 1987, p. 620-627; 690). Mónica (1978, p. 192) também confirma esse aumento salarial dos docentes (de 1920 a 1925, o professor chegou a ganhar mais que um terceiro oficial da burocracia estatal).

Melhorias, porém, que duraram pouco tempo. Com a implantação do Estado Novo, os valores religiosos e a ação missionária dos docentes são novamente acentuados e o estatuto socioeconômico dos docentes decresce, ou seja, eles passam a ser vistos como simples agentes de transmissão do Estado e o seu salário cai. Assim, do ponto de vista econômico, os professores primários retornam à situação difícil que viveram no final do século XIX: os professores do ensino superior ganham três vezes mais do que eles e os professores do secundário, duas vezes (NÓVOA, 1987, p. 768-772). Mónica (1978, p. 189-191) também descreve que, entre 1929 e 1942, o recrutamento dos professores de origem rural aumentou ainda mais, quando os pretendentes "bons e inteligentes" passaram quase sempre a ser designados pelo padre, pelo professor ou pelos notáveis locais". O ingresso no magistério representava, para o campesinato, uma das poucas vias de ascensão na 
hierarquia social, o que constituía melhoria relativamente à classe social de origem. Todavia, o caráter humilde do professor era demonstrado no exíguo ordenado, agravado com o Estado Novo, em que os professores primários estavam nas categorias mais baixas do funcionalismo público.

Mónica (1978, p. 194) relata que o professor, na época de Salazar, ganhava como as "mais baixas ocupações", como contínuo ou datilógrafo. Além disso, anteriormente, os professores trabalhavam três horas e meia por dia na escola e muitos professores recebiam remuneração extraordinária para dar aulas também de tarde, quando tinham mais alunos; outros, por terem necessidade de complementar a renda ${ }^{10}$, davam lições particulares ou exerciam tarefas administrativas. Mas, com o Estado Novo, os professores passaram a ter que trabalhar a tarde, quando tinham mais alunos, sem receber nada a mais; não poderiam ter outro emprego e, depois, ainda foram obrigados a exercer gratuitamente funções de juiz de paz e secretário da junta de freguesia.

A autora descreve que os benefícios sociais praticamente não existiam. Se adoecessem, perdiam o emprego; as grávidas tinham somente 23 dias de licença; as reformas eram tão baixas que morreriam de fome. Existia um subsídio de renda de casa que ajudava no campo, mas que, na cidade, representava muito pouco. Os salários atrasavam constantemente, chegando a meses. O desemprego constituía ameaça permanente; foram reduzidas as vagas nas Escolas de Magistério Primário e, também, o número de postos de trabalho. Por isso, Mónica (1978, p. 194) observa que "A situação era provavelmente ainda pior no caso dos homens colocados nas cidades, que tinham de sustentar a família sem outras fontes de receita, ao passo que uma professora casada sempre contava com o complemento do salário do marido e os professores que viviam no campo cultivavam frequentemente uma pequena porção de terra".

Apesar de as questões de gênero aparecerem um pouco estereotipadas nessa observação, o fato acontecia, na maioria das vezes, e pode ter sido um dos fatores para o afastamento dos homens do magistério. Como pontua Araújo (2000, p. 269; 308-309), apesar de o Estado Novo ser contra o trabalho das mulheres, diante da necessidade delas para ensinar às raparigas e os baixos salários dos homens, achava-se melhor deixar do jeito que estava até ser possível solução melhor. Suas entrevistadas consideravam os salários muito baixos (em diferentes graus) e, até mesmo, "miseráveis", mal chegavam para as necessidades pessoais, 
quanto mais para a família. Assim, as que podiam contar com os maridos tinham vidas menos difíceis.

Assim, Nóvoa (1991) considera que:

O Estado Novo vai prosseguir uma política de degradação do estatuto económico da profissão docente, voltando a apelar aos conceitos de "vocação", de "missão" e de "sacerdócio". A nomeação dos regentes escolares é um dos aspectos desta estratégia, que conduzirá a uma desvalorização do professorado, tanto ao nível econômico como profissional e científico. (NÓVOA, 1991, p. 112)

No fim do Estado Novo, Teodoro (1973, p. 47-53) demarca a "situação extremamente deplorável em que se encontra a profissão docente", agravada ainda mais pelo constante aumento do custo de vida, que não era acompanhado pelo aumento salarial, quando "os vencimentos dos professores se desvalorizaram [...] em mais de 50\%". Benavente (1990, p. 57-58) destaca que a Reforma de Veiga Simão de 1973 marca a vontade de modernização e de deixar para trás a política de empobrecimento. Apesar disso, essa reforma não mudou a situação significativamente. Com ela, entre outras medidas, alarga-se o ensino obrigatório para 8 anos e - reconhecendo a difícil situação dos professores - os professores sobem duas letras na escala de salários da função pública, mas os regentes continuam recebendo 47,4\% menos do que o salário mais baixo do funcionalismo público.

Nóvoa (1987, p. 772-775) considera que, com a Revolução de 1974 e a transformação do papel institucional dos docentes, constata-se a urgência de dar novas remunerações aos docentes, sobretudo aos professores do ensino primário, de acordo com o grau de instrução e a importância social de seu trabalho (decreto 290/75), pois os docentes são definidos como os agentes de transformação social. Constitui-se numa tentativa de transformar o sistema de ensino e valorizar a função docente, inclusive no salário, que sobe. $\mathrm{O}$ autor constata que o salário dos professores do ensino primário passa a se situar entre tenentes e capitães, bem próximo de engenheiros, arquitetos ou juristas de terceira classe, além disso, a diferença entre salários de professor do ensino primário e secundário é reduzida. $\mathrm{O}$ autor conclui que, grosso modo, pela segunda vez na sua história profissional, os professores do ensino primário estão relativamente satisfeitos com sua condição socioeconômica. Mas as coisas parecem dife- 
rentes com relação às mudanças efetivas dentro do estatuto profissional, do papel institucional ou da prática pedagógica do professor primário.

Em 1990, novo avanço remuneratório atinge os professores primários e educadores de infância: institui-se um período transitório de integração dos professores no novo sistema retributivo da função pública, em que os professores primários e educadores da infância são enquadrados no primeiro escalão salarial e os professores do ensino preparatório, secundário e médio entram no terceiro escalão. Em 1992, todos os professores (do ensino primário, infantil, preparatório, secundário e médio) passam a estar na mesma escala remuneratória, sem diferenças salariais pelo grau de ensino em que dão aula, a diferenciação do salário inicial é feita só pelo nível de formação, se são bacharéis ou licenciados ${ }^{11}$ (FENPROF, 1990).

De acordo com o que afirma Sarmento (1991, p. 49), "um estudo actual sobre carreiras dos professores não se esgota na análise do seu estatuto sócio-profissional, mas carece de dar conta das representações dos actores", as representações dos professores que participaram deste estudo ajudam a tirar algumas conclusões sobre a remuneração dos professores. Como percebemos, os avanços salariais mais efetivos dos professores em Portugal aconteceram progressivamente após a ditadura, o que é confirmado por nosso entrevistado José (AV-PT), que, em 1976, iniciou a profissão como professor contratado, recebendo salário muito baixo, um pouco mais do que seu pai, que era operário fabril, e recebia menos do que todos os seus colegas ${ }^{12}$ que zombavam dele, dizendo que, com esse salário, não conseguiria sustentar família (por isso ele também demorou a casar); nesta altura, se pudesse voltar atrás, não escolheria mais a profissão, mas continuou nela por gostar, por questão quase de "fé", e hoje se vangloria de receber mais do que seus colegas, que ainda trabalham mais horas do que ele. Porém, Joaquim (AV-PT) reclama do salário do professor quando comparado com o salário na Espanha.

Dos inquiridos, como referimos anteriormente, dois destacaram que há satisfação por causa da boa remuneração recebida, ${ }^{13}$ dois outros disseram que não existe rendimento inferior ${ }^{14}$ e somente um professor referiu que as pessoas próximas a ele estão insatisfeitas com sua escolha porque o salário é baixo ${ }^{15}$.

Existiram, no entanto, dois inquiridos de AV-PT que citaram que pretendem deixar a profissão por questões salariais. E 14 inquiridos que 
marcaram que o homem não escolhe ser professor do primeiro ciclo por ser uma área com rendimento inferior. Diante de todas essas contradições, parece difícil concluir se o salário é bom ou ruim, mas podemos analisar que essa variedade de opiniões pode ser dependente da origem social dos indivíduos, que acabam por se satisfazer com a melhor opção acessível a eles, pois, como refere Teresa Sarmento (2002, p. 6), a escolha pela profissão docente muitas vezes é "feita em detrimento de outras opções possíveis, com a plena consciência da baixa representação social da profissão e da associada baixa remuneração".

Pardal e Martins (2006, p. 14) também referem que, apesar de a profissão docente ser objeto de forte e generalizada crítica e da falta de expectativa de integração dos alunos na atividade docente após a conclusão do curso, muitos alunos continuam procurando os cursos de formação de professores, quer porque não foi possível entrar em outros $\operatorname{cursos}^{16}$, quer porque se trata de cursos de natureza universitária e que farão parte do imaginário cultural e social dos sujeitos provenientes de determinados grupos sociais, tendo propiciado mesmo níveis consideráveis de mobilidade social no passado.

Afinal, o salário do professor em Portugal é bom? Depende da forma como for analisado. Frente aos países da OCDE, o salário do professor em início de carreira é um dos mais baixos (ver: CRUZ et al., 1988, p. 1287; OECD, 2006, p. 56), mas, no final de carreira, é um dos mais altos (o que geralmente ocorre com 26 anos de exercício profissional). Quando comparado com o Brasil em poder de compra, de acordo com dados da Unesco/OIT (SINISCALCO, 2002, p. 37), o salário inicial de um professor em Portugal equivale a quase o dobro do salário de um professor do Brasil, no final da sua carreira ${ }^{17}$.

A título de comparação, fizemos uma "simulação da cesta básica brasileira ${ }^{18 "}$ em Portugal e retiramos o percentual gasto com "essa cesta" do salário médio do professor público. No ano de 2005, em Portugal, esse percentual seria de 4,17\%. O percentual gasto com essa mesma cesta do salário médio do professor no Brasil (particular e público), em 2003, era de $23,10 \%{ }^{19}$ (o que provavelmente indica que o poder aquisitivo de um professor no Brasil é muito menor do que em Portugal).

Contudo, quando relacionamos o salário do professor primário em Portugal com o salário mínimo no país (ver Gráfico 1) e com outras profissões (ver Gráfico 2), podemos dizer que a média salarial não está tão 
má $^{20}$, pois um professor primário do ensino público tem remuneração bem próxima das profissões para as quais são necessárias as mesmas habilitações acadêmicas (praticamente o mesmo que outras profissões com exigência de habilitação de ensino superior, mais do que o dobro de profissões como vendedores/as, recepcionistas, cozinheiros/as e cerca de $70 \%$ de profissões como engenheiro/ e médico/a $)^{21}$. Além disso, como refere Sarmento (1991), há equiparação do professor primário frente a todos os professores (exceto os do ensino superior) e com os vencimentos dos funcionários públicos com habilitações acadêmica idênticas ou equiparadas.

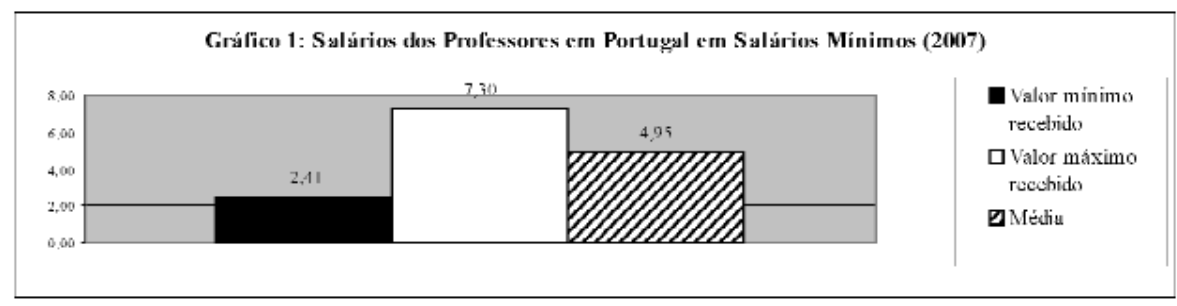

Fonte: Gabinete de Gestão Financeira do Ministério da Educação de Portugal. FENPROF(1990).

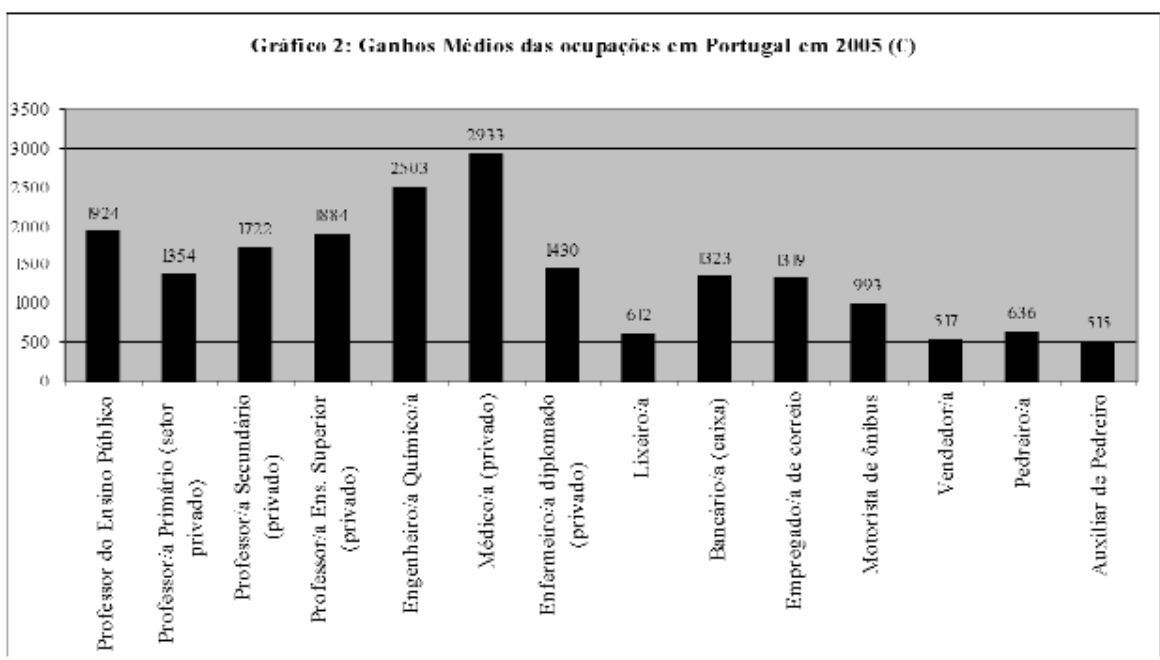

Fonte: OIT-ILO October Inquiry. FENPROF. Gabinete de Gestão Financeira do Ministério da Educ.de Portugal. 
Entretanto, se considerarmos o salário inicial docente, provavelmente ainda há alguns avanços a serem alcançados ${ }^{22}$, principalmente porque a instabilidade de empregos dos professores em Portugal tem feito com que esse salário inicial possa ser prolongado por muitos anos (enquanto ele não for efetivo).

\section{Salário do professor no Brasil}

Podemos afirmar que os professores brasileiros nunca receberam bem, conforme veremos. Campos (2002, p. 2-5) explica que nossos primeiros professores das primeiras letras, após a expulsão dos jesuítas, em 1759, pelo Marquês de Pombal, foram os membros das outras ordens religiosas instaladas no país que atuavam em escolas monásticas, os capelães de engenho e alguns poucos "mestres-escolas" (leigos nomeados para cobrir os lugares vagos). Assim, a autora diz que "esses mestres legaram aos professores atuais o desprestígio da profissão, assim como uma tradição de má remuneração conjugada com a não preparação e inclinação para improvisação".

Fernandes (2000, p. 556-557) expõe que a insuficiência do Subsídio Literário fazia com que existissem poucas escolas e que os salários dos professores fossem muito baixos, no século XIX. O autor descreve a situação de abandono das escolas estatais de Primeiras Letras da Paraíba, em 1821, que não encontravam quem ensinasse pelo baixo salário oferecido. No Maranhão, em 1822, manda-se elaborar editais para contratar professores com ordenados tão baixos que se propunha o dobro para que ele desse para a mínima subsistência. A situação é idêntica em Pernambuco e no Piauí: a carência de professores era atribuída aos baixos salários e à falta de pessoas "instruídas e idôneas" que pudessem ensinar. No Piauí, existiam três escolas quase sempre vagas porque não havia quem aceitasse receber um salário que era menor do que $1 / 3$ do que recebia um feitor de escravos (com cama e mesa).

A igualdade dos salários para professores aprovados é instituída somente com a primeira legislação específica sobre o ensino primário (Lei Geral de 1827), mas, de acordo com Stamatto (2002), existiam brechas para diferenciações salariais, pois, caso não houvesse nenhum aprovado, era autorizada a contratação de candidatos não-aprovados, com a 
condição de pagá-los com salários menores (com menor instrução, as moças eram, possivelmente, as candidatas contratadas, ganhando menos). Hilsdorf (1998, p. 521-522), sobre a contratação da primeira professora aprovada da província de São Paulo, em 1828, mostra que ela recebia $300 \$ 000$ réis anuais, em 1829, enquanto outra professora não-concursada ganhava $76 \$ 800$ réis anuais ${ }^{23}$.

Lílian Wachowicz (citado por Catani, 2000, p. 590) refere a menção de um inspetor do Paraná, segundo quem não é fácil encontrar quem queira ser professor para ganhar $300 \$ 000$ réis anuais, pois qualquer jornaleiro ganha soma muito superior. $\mathrm{Na}$ década de 1860, apresenta que o Estado reduziu o vencimento dos professores públicos (o que também ocorreu em São Paulo, entre 1903-1904), o que repercutiu (em 1867) na baixa frequência da Escola Normal porque os vencimentos não atraíam, especialmente em região fértil de recursos. Campos (2002, p. 2-5) também descreve que, por volta de 1880, a remuneração era muito baixa, só poderia exercê-la quem tivesse atividade paralela ou a família para apoiar (como as mulheres), ou não tivesse encontrado nenhuma outra atividade melhor.

Schueler (2005, p. 384) indica que os professores na corte, entre nas décadas de 1870-80, eram geralmente provenientes de classes pobres, recebiam pouco e precisavam do salário para sobreviver, não tinham condições de aprimorar os estudos e frequentar a Escola Normal, além de terem representações sobre si mesmos de pobreza, austeridade, sacrifícios, sacerdócio e missão.

Almeida (1998, p. 129-131) conclui que as reclamações sobre vencimentos parecem ser uma constante junto ao professorado do Brasil, ao longo das décadas. Nas primeiras décadas do século XX, apesar do discurso dos educadores e intelectuais que atribuíam ao magistério primário características que mais os aproximavam de um sacerdócio ou de uma missão do que do trabalho assalariado, encontram-se escritos em revistas que demonstram que os professores não somente reclamaram dos baixos vencimentos da categoria, mas procuraram organizar-se em associações, ou seja, o propalado prestígio não impedia que a categoria fosse extremamente mal-remunerada. Poucos se dedicavam com afinco ao ensino. Em 1901, um regulamento proibia que os professores exercessem outras atividades (além das aulas particulares). Em 1903, encontram-se trechos dizendo que ou abandonava-se o magistério ou ter- 
se-ia uma vida de dificuldades, pois a profissão não dava para sustentar uma família. Em 1906 e 1918, a denúncia de que os vencimentos são insuficientes continua: os salários recebidos não mais bastavam para as despesas básicas e necessidades mais urgentes da vida por estarem situados ainda em patamares iguais aos do ano de 1891 (mesmo em 1891, o salário já era insuficiente e, em 1905, eles tinham sido rebaixados).

Kuleska (1998, p. 70) descreve um discurso do governador do Piauí, ao reabrir a escola Normal, em 1910, no qual se diz que as mulheres são preferidas para desempenhar a docência por causa da sua vocação (afeto e aptidão para ensinar crianças) e porque a exiguidade dos vencimentos que o Estado oferece aos professores não permite que o homem exerça essa função, sendo a mulher mais resignada e fácil de contentar, e quase sempre assistida pelo marido, pelo pai ou pelo irmão, por isso podendo aceitar o professorado e desempenhá-lo com assiduidade e dedicação, apesar da baixa retribuição.

Esse é um discurso que prolifera. Tanuri (2000, p. 66) mostra que o fato de o magistério ser a única profissão que conciliava as funções domésticas da mulher gerava preconceitos que bloqueavam sua profissionalização. No entanto, o magistério feminino apresentava-se como solução para o problema de mão-de-obra para a escola primária (pouco procurada pelo elemento masculino, em vista da reduzida remuneração), por isso as órfãs eram destinadas, em várias províncias, ao magistério primário, que oferecia parcos salários. Louro (1989, p. 35-36) também refere que a vinculação do magistério com a vocação supõe doação, o que leva a certa desconsideração do salário, além disso, o fato de serem as mulheres a ocupar essa atividade serve para justificar os baixos vencimentos, pois, "usualmente, elas não são o único ou o principal componente do orçamento familiar e, supostamente, contentam-se com menor remuneração".

Almeida (1998, p. 158; 209) encontra estudos que mostram que os professores, no início do século $\mathrm{XX}$, muitas vezes recebiam salários menores do que pedreiros, carpinteiros e carroceiros. Contudo, também encontra mulheres do interior paulista, na década de 1930 e 1940, que achavam bom o salário na época em que lecionavam, o que lhes assegurava uma vida melhor. Assim, analisa que não foi só o salário que levou ao afastamento do homem do magistério, mas também questões de identidade sexual, movidos que estavam pelo fato de a profissão ter se 
tornado feminina, pois, apesar de estar entre as profissões malremuneradas, ela não se situava no último lugar da escala de valores salariais, havendo profissões consideradas masculinas que pagavam tão mal quanto o magistério ${ }^{24}$. Assim, ao analisar a imprensa, a autora assegura que a profissão docente nunca foi valorizada, ao contrário, sempre foi alvo de péssima remuneração salarial e a sua não-valorização antecede o ingresso das mulheres nesse campo profissional.

Ângela Martins (1996, p. 159-160), em sua tese, analisa que, na segunda metade da década 1940 e ao longo da década de 1950, a profissão de professora era uma das poucas opções para o universo feminino e, no Rio de Janeiro, ao formar-se, a professora tinha emprego garantido na rede pública de ensino, com remuneração bastante significativa, "principalmente quando levamos em conta ser esta uma profissão eminentemente feminina, e, consequentemente, não ser considerada profissão de 'arrimo de família"'. No final da década de 1940, a maioria das professoras primárias cariocas recebia mais de dois salários mínimos, quando o salário mínimo tinha um poder de compra significativo (supria as necessidades básicas, como alimentação, habitação, vestuário, etc.), o que tornava a remuneração cobiçada pelas normalistas.

No mesmo período, Gouveia (1957, p. 33-34) não encontra tão boa recepção ao salário docente, pois, ao analisar os professores primários do estado do Rio de Janeiro, em 1956, encontra 69\% dos/as docentes insatisfeitos/as com o salário. Esses professores/as eram majoritariamente do sexo feminino, com idade de 25 a 43 anos, de cor branca, provenientes de família de classe média, com nível de instrução formal superior ao de seus pais, diplomadas por escola normal, onde ganhavam menos de dois salários mínimos, e que contribuíam para o orçamento familiar, mas que não eram as únicas responsáveis pelas despesas da família.

Ângela Martins (1996, p. 161), no entanto, demarca que o poder de compra do salário mínimo mantinha o mesmo patamar da década de 40 e que a professora primária carioca ganhava mais do que essa média. Por esses e outros motivos, ela denomina esse período (década de 40 e 50) de "anos dourados" da docência, com valorização social e monetária.

Mas essa valorização monetária provavelmente só era representativa em uma profissão eminentemente feminina, que muitas vezes não sustentava sozinha a família, e também foi por curto período, pois, na 
década de 1960, vários autores destacam sua crescente desvalorização. Guacira Louro (1989, p. 36) demarca que, nos anos 60, há o empobrecimento das classes assalariadas, quando a ditadura reduz os espaços para resistência e acentua o processo de proletarização do magistério. Quando as normalistas eram a categoria mais alta, os salários de quem não tinha o Normal eram rebaixados, mas, com o aumento do número de normalistas e o surgimento dos especialistas, os professores passam a receber os níveis de salários mais baixos da sociedade, enquanto uma proporção mínima de especialistas da educação passa a fazer parte do magistério, com salários baixos, porém mais altos do que os dos Normalistas.

Tanuri (2000, p. 80) afirma que a deterioração das condições de trabalho e de remuneração acompanharam o processo de expansão do ensino de primeiro grau. Para Vieira (2004, p. 16), essa expansão das matrículas se deu pela contenção e pelo rebaixamento salarial (que atingiu mulheres e homens), o que Cury (2000, p. 574) descreve quando diz que a Constituição Federal de 1967 aumentou o tempo de escolaridade para oito anos, mas retirou a vinculação constitucional de recursos, com a justificativa de maior flexibilidade orçamentária. Assim, havia necessidade de crescimento da rede física escolar, mas existiam parcos recursos para tal. O corpo escolar docente "pagou a conta" da expansão escolar com duplo ônus: o rebaixamento de seus salários e a consequente duplicação ou triplicação da jornada de trabalho. Além disso, a maior demanda fez com que os contratos precários crescessem e os concursos para professores fossem reduzidos.

Como explicam Bruschini e Amado (1988, p. 5), o magistério começou a ser considerado como profissão feminina sob a influência de correntes de pensamento que consideravam a mulher biologicamente capaz de socializar as crianças, como parte das suas funções maternas. Os baixos salários oferecidos reforçavam essa associação, a ponto de se encarar como desonroso e até humilhante, para o homem, o exercício dessa profissão, como mostram autoras da década de 1960 e 1980, que também referem que o baixo salário era, para a maioria das professoras (que trabalhavam mais de 40 horas semanais), o principal ou o único meio de sustento da família.

Apesar de terem alguns direitos assegurados na década de 1970, como jornada de trabalho compatível, salários não diferenciados dos salários masculinos, aposentadoria aos 25 anos de serviço, licenças de 
saúde e maternidade, entre outros benefícios, a profissão continuava sendo mal-remunerada (ALMEIDA, 1998, p. 29).

Valle (2000, p. 8) questiona se esses "ganhos" 25 são bons, em contraste com o que recebem. Será que os professores não trocariam tantas "benesses" por um salário condigno, que lhes permitisse trabalhar em uma única escola? A autora analisa os contracheques de um professor do município do Rio de Janeiro (que, até 1975, era o Estado da Guanabara) das décadas de 1960 a 1980 e verifica que os mais baixos salários foram pagos durante os anos 1960 e 1961 e no período de 1980 a 1983. Além disso, afirma que a valorização salarial do magistério tem desconsiderado a experiência profissional acumulada do professor e sua formação acadêmica ao longo dos anos ${ }^{26}$. Pesquisa de Paiva, Junqueira e Muls (citado por NUNES, 2000, p. 22) sobre os salários dos docentes da rede municipal do Rio de Janeiro também destaca a perda salarial principalmente dos professores com maior nível de escolaridade e experiência. O salário de um professor em 1994 equivalia a apenas 15\% do salário que era recebido em 1979.

Assim, como atesta Almeida (1998, p. 29), "Esse processo, até hoje, não dá mostras de reversibilidade, atrelada que está essa má remuneração aos serviços prestados pelo Estado à população e não ao fato do magistério possuir maioria feminina, como tem sido comumente apontado"27.

Podemos verificar que tal má remuneração continua até os dias atuais, quando o professor brasileiro tem salário, apontado por Siniscalco (2002, p. 37), com um dos menores poderes aquisitivos frente a vários países do mundo (no estudo, tem a terceira pior remuneração dos professores primários). Além disso, ao relacionarmos o salário do professor primário no Brasil ao salário mínimo no país e a outras profissões (ver Gráfico 3), podemos dizer que a média salarial continua muito ruim, pois um professor primário tem remuneração bem próxima das profissões para as quais são necessárias habilitações acadêmicas muito menores, por exemplo, recebendo menos que pedreiro, vendedor, carteiro, motorista de ônibus, enfermeiro auxiliar (sem diploma de nível superior), entre outros; e muito menos da metade do que recebem os profissionais com exigência de habilitação de ensino superior (enfermeiros, médicos, engenheiros, químicos, psicólogos, etc.). 


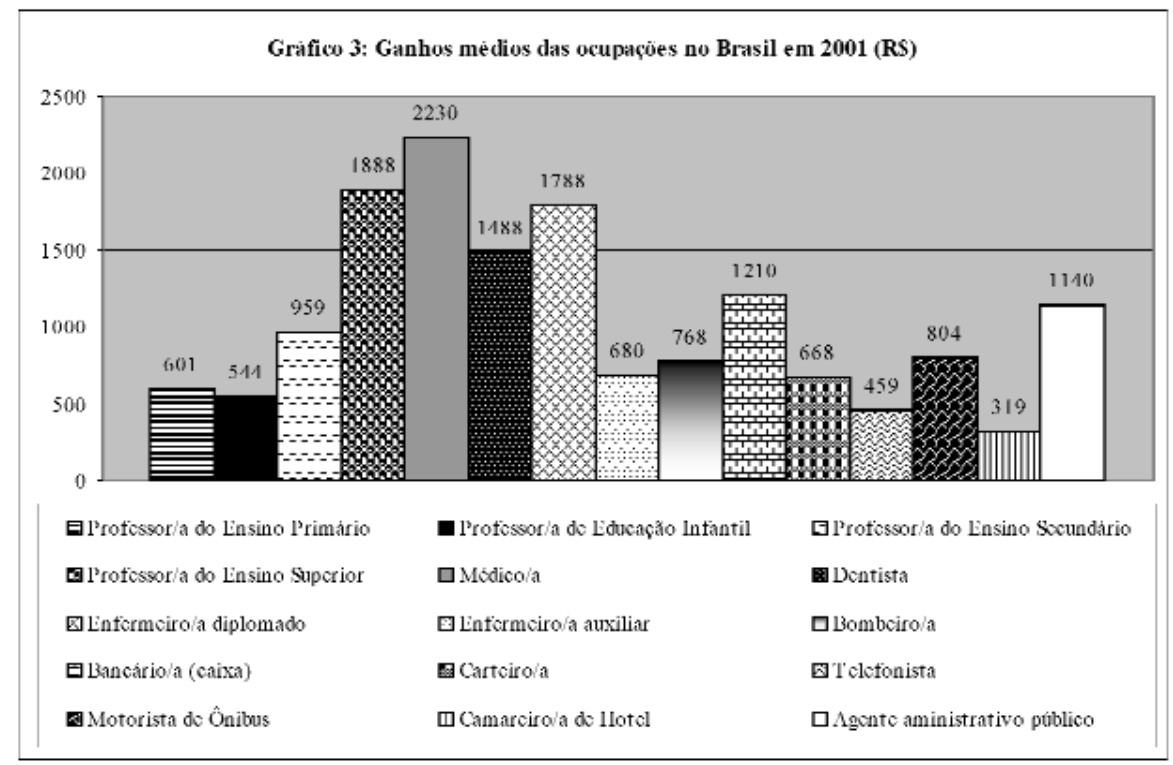

Fonte: OIT-ILO October Inquiry.

Mesmo se considerássemos a carga horária do professor como menor ${ }^{28}$ frente às outras profissões, mesmo assim, proporcionalmente, ele ainda teria salário mais baixo do que muitas profissões, como bancário e agente administrativo público (com habilitações menores ou iguais aos professores primários, se considerarmos aquele que ainda tem somente o curso normal de médio), e bem menor do que o das profissões com necessidade de habilitação de nível superior ${ }^{29}$. Outro agravante é que quando comparamos ao salário dos outros professores e profissionais da educação (que, na maioria das vezes, tem carga horária menor do que a do professor primário), o salário do professor primário é muito menor, o que causa nele um desejo de progressão na carreira para essas outras áreas da educação (conforme veremos na próxima seção).

Mesmo com essa contínua má remuneração do magistério, Abreu (2002, p. 1; 6) verifica pequeno aumento do índice de homens que ingressaram na Escola Normal e o aumento da procura pelos concursos públicos para professores primários no final da década de 1990, o que o autor relaciona mais ao desemprego crescente no país do que ao desejo de ensinar crianças. 
Catani, Bueno e Sousa (2000, p. 61) também destacam essa associação da busca de homens pela profissão docente com a necessidade, ou seja, este considerado "baixo salário" pode ser muito para algumas pessoas $^{30}$. Em uma das narrativas colhidas, um professor revela grande desejo de se tornar professor, significando vir a ser alguém na vida, vencer na cidade grande ${ }^{31}$. Também mostra a necessidade de mudar de moradia, começar a trabalhar cedo, de mudar para a cidade, o desejo de poder frequentar uma "escola paga" (o que possibilitou ter êxito no vestibular particular).

Assim, o fato de existirem 25 professores inquiridos do RJ-BR (cerca de $17 \%$ da amostra) ${ }^{32}$ que descreveram, na sua justificativa, que havia insatisfação das pessoas próximas com a remuneração recebida e, ao mesmo tempo, a existência de três inquiridos do RJ-BR que citaram a satisfação das pessoas próximas associada à boa remuneração recebida não é incoerente. Ao contrário, mostra que os professores têm diferentes referenciais, como indicam as justificativas a seguir:

"Existe a questão do status profissional da figura do professor, mal ou bem a remuneração não é das piores (IBR71)"; "Alguns só estão satisfeitos porque estou recebendo um salário superior à maioria da população (pai, parentes, amigos)" (IBR81); "A satisfação vem do fato de a profissão ser estável e ter uma remuneração relativamente boa. A insatisfação poderia ser por acharem que eu deveria escolher uma profissão que tivesse um salário melhor, como médico ou advogado" (IBR131); "A satisfação deve-se a ter alguém na família que tem um bom emprego e a insatisfação deve-se ao fato do professor não ser bem-remunerado" (IBR130).

Ou seja, o salário do professor brasileiro é baixo, mas ainda existem salários e/ou empregos considerados piores (por exemplo, os braçais). Um salário baixo pode ser considerado bom para aqueles que vêm de famílias que recebem ainda menos do que eles e desejável para aqueles que veem na docência (que ainda tem carência de profissionais) a melhor chance de ter um emprego considerado importante e estável, frente à escassez das oportunidades de emprego. 


\section{Considerações sobre o estatuto financeiro e social}

De acordo com as justificativas dos professores entrevistados e inquiridos sobre a consideração das pessoas próximas sobre sua escolha profissional, verificamos que há uma contraposição entre a satisfação e a insatisfação destas e que não há unanimidade sobre se a profissão é boa ou é ruim.

Notamos grande diferença entre a opinião das pessoas próximas aos professores do sexo masculino de AV-PT e do RJ-BR: nas entrevistas, os professores do RJ-BR destacam a baixa remuneração dos professores, o que é referido pelos professores de AV-PT como antigamente mais baixa e atualmente somente considerada baixa no início da carreira e quando comparada com outros países. Nos inquéritos, enquanto somente um inquirido de AV-PT descreveu na sua resposta que havia insatisfação destas com a remuneração recebida, existiram 25 inquiridos do RJ-BR (cerca de $17 \%$ da amostra) que citaram essa insatisfação. Já a satisfação das pessoas próximas associada com a boa remuneração recebida foi citada por dois inquiridos de AV-PT e por três inquiridos do RJ-BR (o que, a princípio, parece incoerente).

Isso mostra que os referenciais dos diferentes professores com relação ao salário do professor não são os mesmos (mesmo dentro de cada localidade), pois os mesmos aspectos (como prestígio social e rentabilidade) foram ponderados de diferentes formas, em ambos os países, o que nos levou a indagar se o professor tem ou não prestígio social. Seu salário é bom ou ruim?

Almeida (1998) explica que até a década de 1940 no Brasil:

A escolha profissional passava necessariamente por essa ideia de frequentar um curso de qualidade, que dava uma excelente cultura geral e preparo adequado para exercer uma profissão que era reputada como digna e prestigiada, fosse ela exercida por homens ou por mulheres. A figura da mulher que lecionava era bem aceita e apontada às moças como exemplo de honestidade e ideal a ser seguido. $\mathrm{O}$ mesmo acontecia com o professor. A família tinha a figura da professora e do professor em grande consideração e estes detinham um prestígio social que estava em claro desacordo com a remuneração salarial percebida [...], desfrutava um prestígio advindo do saber, e não do poder aquisitivo. (ALMEIDA, 1998, p. 191) 
Assim, os professores brasileiros tinham prestígio social que contrastava com sua remuneração, prestígio proveniente do saber que detinham, o que aconteceu também em Portugal até o fim do Estado Novo, quando seu papel é exaltado (tanto como agentes do progresso e da ascensão social de outrem quanto como missionários). Como refere Esteve (1992, p. 41), até as décadas de 1940 e 1950 reconhecia-se o professor com status social e cultural elevado porque se estimava o seu saber, sua abnegação e sua vocação.

No entanto, Mónica (1978, p. 199) relata que, em Portugal, mesmo durante Estado Novo, os membros das classes dominantes consideravam a docência uma atividade declaradamente desprezível, apenas própria para os "pobres". Já nas pequenas comunidades rurais, o padre e o professor primário pertenciam às camadas superiores, mas a atitude dos camponeses para com eles se revestia de certa ambiguidade: admiração por ele ser da classe baixa, ressentimento por ele ter subido na vida, hostilidade por ser uma autoridade repressiva estranha.

Jesus (2002, p. 28-29) confirma que, no passado, os professores do ensino primário e os párocos eram "os principais agentes culturais nas aldeias e vilas e os professores do ensino secundário pertencessem à elite social das cidades", situação que, no entanto, não ocorre no presente, pois, atualmente, a imagem social dos professores está em declínio (o relatório Braga da Cruz já indica o baixo estatuto aos professores, oferecido, principalmente, por eles mesmos). Essa perda de prestígio está ligada à alteração do papel tradicional dos professores no meio local. Ele aponta diversos fatores para justificar a diminuição do prestígio, como: obrigatoriedade escolar, massificação do ensino, impacto dos meios de comunicação social, desvalorização do saber escolar, baixo salário, feminização, elevado número de professores e baixa qualidade acadêmica de muitos deles. $\mathrm{O}$ autor também refere a contribuição das alterações nos valores sociais para a perda do prestígio, a depreciação do conhecimento e da vocação frente aos valores individualistas e economicistas.

Esteve (1992) explica melhor essa mudança de valores:

No entanto no momento actual a nossa sociedade tende a estabelecer o estatuto social com base no nível de rendimento. Os conceitos de "saber", "abnegação" e "vocação" caíram a pique na valorização social. Para muitos pais a ideia de alguém decidir ser professor não se associa com o sentido de vocação, mas antes com a ideia de não ter capacidade para fazer "algo 
melhor", quer dizer, para dedicar-se a algo que dê mais dinheiro. Por certo que o salário dos professores constitui um elemento mais da crise de identidade que afecta os professores. [...] Este factor, que em si mesmo não teria grande importância, contribui como um elemento mais para o mal-estar docente, sobretudo quando o professor o associa com o aumento de exigências e responsabilidades que se lhe pedem no seu trabalho. (ESTEVE, 1992, p. 41)

Assim, percebemos que a sobrevalorização do aspecto econômico contribui para a desvalorização de profissões mal-pagas, o que acaba incentivando para que muitos ingressem nessas profissões por falta de alternativa profissional (ou que a mentalidade da sociedade sobre os que ingressam nessa profissão seja a de que eles não tiveram alternativas). O autor ainda completa, em outro texto (1995, p. 105), que há vinte anos "o professor do ensino primário era uma figura social relevante, sobretudo no meio rural" e que, atualmente, "é visto como um pobre diabo que não foi capaz de arranjar uma ocupação mais bem remunerada". Com a interiorização dessa mentalidade, o mal-estar incide sobre os professores, que passam a abandonar ou a pensar em abandonar a docência.

Mas, nessa análise, o estatuto social é sobretudo estabelecido com base em critérios econômicos, associando a desvalorização social à desvalorização salarial. Como explicar, então, o considerável aumento da desvalorização social da profissão docente em Portugal frente à crescente valorização salarial? Será porque ainda seja veiculado que o professor tenha rendimento inferior? Será porque o professor não é considerado importante na atual sociedade?

A OCDE, em 1989 (citado por Alves, 1994, p. 33), elucida que essa perda de prestígio residiria "em três grandes vectores: o elevado número de professores, o nível de qualificação, que nunca foi muito elevado, e a feminização crescente e predominante na profissão". Mas a explicação pode ser mais complexa do que essa (até porque, como já vimos, a feminização é posterior ao baixo estatuto financeiro da profissão e a qualificação sempre foi baixa).

Teodoro (1973, p. 17) aponta que a desvalorização da função docente não está "relacionada com o acesso ao ensino de novas camadas da população, salvo para quem ainda conceba o direito à educação como um privilégio de classe. A desvalorização da função docente é sim o 
resultado intencional de quatro políticas convergentes: econômica, social e escolar, cultural e antilaica" (grifos do autor). E explica que todas as políticas intencionais de desvalorização da função docente ${ }^{33}$ fizeram com que " $O$ ensino fosse sendo entregue a pessoal docente não qualificado profissionalmente e sujeitos a condições de trabalho que não respeitam os mais elementares direitos de qualquer trabalhador" (TEODORO, 1973, p. 21).

Outro fator mais recente, lembrado por Nóvoa (1988), é que estamos em uma sociedade mediatizada pela informação, na qual os professores não têm mais o monopólio do saber. Anteriormente, o prestígio era proveniente da "alta missão que lhe era confiada", (mas não podemos esquecer de que essa função missionária do professor serviu para justificar seus baixos rendimentos); entretanto, hoje o papel da escola não é mais o mesmo (apesar de ainda ser importante) e o professor não é mais um dos únicos representantes da cultura acadêmica, o que ajuda a explicar tal decadência no seu prestígio social.

Como percebemos com o relatório Braga da Cruz (1988, p. 1190-1191), a perda de exclusividade do saber tem consequências no prestígio social dos docentes, pois, com o aumento da profissionalização dos professores portugueses nos últimos tempos, "é cada vez mais difundida a percepção de que o seu estatuto socioprofissional se tem vindo progressivamente a degradar, sobretudo em termos do reconhecimento público e do prestígio social que é conferido à profissão”.

Como indica o relatório, isso é preocupante, porque os professores são profissionalmente condicionados pelo meio social em que a escola e o sistema de ensino se inserem. Esse prestígio e o reconhecimento social que os professores têm são determinados por vários fatores, como a extensão numérica, a qualificação científica e profissional, a composição sexual, as condições de vida e de mobilidade social que a profissão proporciona, entre outras.

Nóvoa (1995c, p. 22-23; 30) observa que "os professores constituem um dos mais numerosos grupos profissionais das sociedades contemporâneas, o que, por vezes, dificulta a melhoria do seu estatuto socioeconômico". No entanto, o autor constata, nas sondagens publicadas pela imprensa e nos relatórios sobre a situação dos professores, que, apesar de tudo, a imagem da profissão é bastante positiva, ou seja, que o prestígio da profissão docente permanece intacto. Esse paradoxo acontece por causa da brecha existente entre a "visão idealizada e a reali- 
dade concreta do ensino. É nesta falha que se situa o epicentro da crise da profissão docente".

Enfim, como Nóvoa (1995c, p. 29) demonstra:

O estatuto social e económico é a chave para o estudo dos professores e da sua profissão. Num olhar rápido temos a impressão que a imagem social e a condição económica dos professores se encontram num estado de grande degradação, sentimento que é confirmado por certos discursos das organizações sindicais e mesmo das autoridades estatais. Mas cada vez que a análise é mais fina os resultados são menos concludentes e a profissão docente continua a revelar facetas atractivas. [...] É evidente que há uma perda de prestígio, associada à alteração do papel tradicional dos professores no meio local: os professores do ensino primário já não são, ao lado dos párocos, os únicos agentes culturais nas aldeias e vilas da província; os professores do ensino secundário já não pertencem à elite social das cidades, cujo recrutamento não passa apenas por critérios escolares. E é verdade que os professores não souberam substituir estas imagens-força por novas representações profissionais.

Ou seja, apesar de parecer que o estatuto social e econômico dos professores está em total degradação, perdendo o prestígio que eles sentiam que tinham, em uma análise mais fina, não podemos concluir isso, pois a profissão ainda tem seus atrativos. Como Jesus (2002, p. 50) também considera, "não podemos negar o facto de que esta profissão também comporta, na actualidade, algumas vantagens comparativamente a muitas outras profissões para as quais são requeridas as mesmas habilitações acadêmicas". Mas o elevado nível de mal-estar na profissão requer a melhoria da situação dos professores e o salário é a melhoria mais visível e valorizada na atual sociedade de consumo. Assim, conclui-se que:

os salários de base dos professores deveriam ser aumentados substancialmente, sobretudo nos primeiros anos de docência, de forma a tornar a profissão docente "competitiva", comparativamente a outras profissões para as quais são necessárias as mesmas habilitações acadêmicas. Tal medida permitiria atrai candidatos com melhores resultados acadêmicos e, logo, provavelmente mais eficazes, podendo contribuir para a melhoria da qualidade do ensino e para o reconhecimento da importância da profissão docente na nossa sociedade. (JESUS, 2002, p. 84)

Conforme já mencionamos, em Portugal, os salários iniciais na profissão docente não têm sido competitivos, assim como os salários dos 
professores primários como um todo no Brasil. Como Jesus analisa, esses salários devem ser aumentados com as finalidades de atrair os potenciais professores com melhores qualificações, manter os professores e incentivar seu empenho em exercício ${ }^{34}$. Isso teria repercussões na imagem docente, o que poderia aumentar seu estatuto social.

Apesar de o autor referir que o salário é condição necessária, mas não suficiente, para a motivação profissional, pois a motivação intrínseca dos professores não aumenta com incentivos salariais, ele também destaca que tais incentivos não podem ser analisados de forma descontextualizada ou despersonalizada, pois é preciso estudar o projeto profissional do professor e do potencial professor (fazer orientação motivacional), pois todos os fatores são importantes. Se traduzirem suas metas, enfim, os fatores extrínsecos (incluindo os salariais) também podem contribuir para o empenho dos professores e devem estar presentes para evitar a insatisfação profissional (JESUS, 2002, p. 81; 92; 228).

Não podemos esquecer, como ressalta o relatório de Cruz et al. (1988, p. 1191; 1247), que "o que pensa dos professores a opinião pública e o que pensam os professores de si mesmos são dois determinantes decisivos do status social dos professores", mas também que a opinião dos professores sobre o prestígio da sua profissão foi pior do que o da opinião pública, que ainda considerava o professor com considerável prestígio social.

Evidencia-se, também, nesta investigação, que a opinião das pessoas próximas sobre a escolha da profissão docente é mais favorável do que desfavorável, mesmo assim, os relatos de nossos entrevistados mostram que a insatisfação dessas pessoas (mesmo que seja menor do que a satisfação) os atinge fortemente e impetra, muitas vezes, sua opinião sobre sua própria profissão.

Portanto, consideramos que alguns dos motivos do declínio do seu prestígio, mesmo frente ao aumento da remuneração em Portugal (Nóvoa, 1987), são a perda do monopólio do saber e o aumento da quantidade de professores, que, além de dificultar o aumento da remuneração, proporcionou maior difusão dessa profissão, ou seja, eles deixaram de ser raros, com a expansão da escola de massas, e, por isso, perderam o estatuto de "únicos prestigiados".

Vale ressaltar que a representação de prestígio que a profissão tinha (até o Estado Novo, em Portugal, e até a década de 70, no Brasil) 
não é anterior à entrada das mulheres na docência e que o baixo estatuto financeiro já existia antes da feminização da profissão, isso permite que demonstremos que o sexo não tem sido grande motivador nem do estatuto financeiro nem social da profissão.

Mas tal remuneração pode atrair (ou não) os homens para a profissão. Como Williams (1995, p. 174) analisa, provavelmente um salário mais alto não atrairia mais homens para "ocupações femininas", mas muitos dos seus entrevistados afirmaram que a maioria dos homens não consideram entrar nessas profissões porque têm opções de trabalho com melhores pagamentos e/ou acreditam que a questão salarial pressiona o homem, devido às suas expectativas de sustentar a família.

Muitos dos nossos inquiridos e entrevistados também reforçaram essa tese, pois 84 inquiridos do RJ-BR (cerca de 56\% da amostra) e 14 de AV-PT (cerca de $23 \%$ da amostra) acreditam que poucos homens escolhem ser professor primário porque é uma área com rendimento inferior. Verificamos também que muitos professores que pretendem abandonar a profissão são movidos por questões salariais e muitos acreditam que existem poucos homens no magistério primário devido ao baixo salário.

Outra questão a ser pontuada é a de que, no Brasil, a questão da má remuneração (com as consequentes más condições de vida dos professores) ainda está associada à queda de prestígio, mas o prestígio social e financeiro ainda existe, principalmente junto às camadas mais desfavorecidas da população, que ainda percebem a educação como uma forma de ascensão social, e a profissão docente como um ofício melhor entre as profissões que lhes são acessíveis.

Nóvoa (1989, p. 448) assinala que, nas últimas décadas, assistiuse à expansão dos sistemas educativos ${ }^{35}$, que apresentam sintomas da crise generalizada da escola, incapaz de dar respostas coerentes às necessidades sociais atuais ${ }^{36}$. Por isso, os professores sentem-se desvalorizados e desapoiados, os alunos sentem-se desmotivados, as famílias, intranquilas, os empresários reclamam da falta de qualidade do ensino. Precisamos de outra escola e outro professor, por isso eles têm de redefinir seu papel, dado que, como reflete em outro texto (1995c, p. 30-31), pertence à escola o papel primordial na tarefa de pensar o futuro, pois nela concentra-se um dos mais numerosos grupos profissionais e também um dos mais qualificados, do ponto de vista acadêmico, que se encontra relativamente 
protegido dos confrontos políticos, das competições comerciais e das tentações gestionárias. É preciso criar condições para "que o conjunto dos professores projecte o futuro desta profissão, que parece reconquistar, neste final de século, novas energias e fontes de prestígio".

\section{Referências}

ABREU, J. J. V. D. A inserção do professor do sexo masculino no magistério primário de Teresina (PI). II Congresso Brasileiro de História da Educação: História e Memória da Educação Brasileira, Natal, Brasil, 2002.

ALMEIDA, J. S. D. Mulher e educação: a paixão pelo possível. São Paulo: Unesp, 1998.

ALVES, F. C. A (in) satisfação docente. Revista Portuguesa de Pedagogia, v. 28, n. 1, p. 29-60, 1994.

ARAÚJO, H. C. Pioneiras na educação: as professoras primárias na viragem do século: contextos, percursos e experiências, 1870-1933. Lisboa: Instituto de Inovação Educacional, 2000.

BENAVENTE, A. Escola, professoras e processos de mudanças. Lisboa: Livros Horizontes, 1990.

BRUSCHINI, C.; AMADO, T. Estudos sobre mulher e educação. Cadernos de Pesquisa, v. 64, p. 4-13, Fevereiro. 1988.

CAMPOS, M. C. S. D. S. Formação do corpo docente e valores na sociedade brasileira: a feminização da profissão. In CAMPOS, M. C. S. D. S.; SILVA, V. L. G. D. (Eds.), Feminização do magistério: vestígios do passado que marcam o presente. Bragança Paulista: Edusf, 2002. p. 13-37.

CARVALHO, R. D. História do ensino em Portugal: desde a fundação da nacionalidade até o fim do regime de Salazar-Caetano. Lisboa: Fundação Calouste Gulbenkian, 1986.

CATANI, D. B. Estudos de história da profissão docente. In LOPES, E. M. T.; FILHO, L. M. F. ; VEIGA, C. G. (Eds.), 500 anos de educação no Brasil. Belo Horizonte: Autêntica, 2000.

CATANI, D. B., et al. Os homens e o magistério: as vozes masculinas nas narrativas de formação In CATANI, D. B.;BUENO, B. O.; SOUSA, C. P. (Eds.). A vida e o ofício dos professores. São Paulo: Escrituras, 2000.

CRUZ, M. B. D., et al. A situação do professor em Portugal. Análise Social, v. XXIV, n. 103-104, p. 1187-1293, 1988.

CURY, C. R. J. A educação como desafio na ordem jurídica. In LOPES, E. M. T.; FILHO, L. M. F.; VEIGA, C. G. (Eds.). 500 Anos de Educação no Brasil. Belo Horizonte: Autêntica, 2000.

ESTEVE, J. M. O mal-estar docente. Lisboa: Escher, 1992.

ESTEVE, J. M. Mudanças sociais e funções docentes. In NÓVOA, A. (Ed.). Profissão Professor. 2 ed. Porto: Porto Editora, 1995. p. 93-124.

EURYDICE. Glossário europen da educação. Brussels: Eurydice, 2001. v. 3.

FENPROF. Jornal da FENPROF, v., n. 73, supl., Dez. 1990.

FERNANDES, R. A instrução pública nas cortes gerais portuguesas. In LOPES, E. M. 
T.; FILHO, L. M. F.; VEIGA, C. G. (Eds.), 500 anos de educação no Brasil. Belo Horizonte: Autêntica, 2000.

GALBRAITH, M. Understanding career choices of men in elementary education. Journal of Educational Research, v. 85, n. 4, p. 246-253, March/April. 1992.

GOUVEIA, A. J. Professores do Estado do Rio. Revista Brasileira de Estudos Pedagógicos. INEP/MEC, v. 28, n. 67, p. 30-63, Jul-Set, 1957.

HILSDORF, M. L. S. Mestra Benedita ensina primeiras letras em São Paulo (1828-58). Leitura e Escrita em Portugal e no Brasil, 1500-1970, Porto, 1998.

JESUS, S. N. D. Motivação e formação de Professores. Coimbra: Quarteto Editora, 2002.

KULESZA, W. A. A institucionalização da escola normal no Brasil (1870-1910). Revista brasileira de estudos pedagógicos, v. 79, n. 193, p. 63-71, set./dez. 1998.

LOURO, G. L. Magistério de $1^{\circ}$ grau: um trabalho de mulher. Educação e Realidade, v. 14, n. 2, p. 31-39, jul/dez. 1989.

MARTINS, Â. M. S. Dos anos dourados aos anos de zinco. Tese (Doutorado em Educação). Universidade Federal do Rio de Janeiro (UFRJ), Rio de Janeiro, 1996.

MÓNICA, M. F. Educação e sociedade no Portugal de Salaz̧ar. Lisboa: Presença/Gabinete de Investigações Sociais, 1978.

NÓVOA, A. $<<L e>>$ temps des professeurs. Lisboa: Instituto Nacional de Investigação Científica, 1987.

NÓVOA, A. Um tempo de ser professor. Lisboa: [s.n.], 1988.

NÓVOA, A. Profissão: professor. reflexões históricas e sociológicas. Análise Psicológica, v. 1-2-3, n. VII, p. 435-456, 1989.

NÓVOA, A. Os professores: quem são? Donde vêm? Para onde vão? In: STOER, S. (Ed.), Educação, Ciências Sociais e Realidade Portuguesa. Uma abordagem Pluridisciplinar. Porto: Afrontamento, 1991. p. 59-129.

NÓVOA, A. O passado e o presente dos professores. In NÓVOA, A. (Ed.). Profissão professor. 2 ed. Porto: Porto Editora, 1995c. p. 13-34.

NUNES, C. Formação docente no Brasil: entre avanços legais e recuos paradigmáticos. Teias: Revista da faculdade de Educação/UERJ, n. 1, p. 16-55, junho, 2000.

OECD. Education at a glance 2006: OECD, 2006.

PARDAL, L.; MARTINS, A. As representações sociais e o sentido das escolhas académicas. Universidade de Aveiro, 2006.

SARMENTO, M. J. Professores do ensino primário: a carreira e/ou a vida. Braga: Colecção Comunidade Educativa, 1991.

SARMENTO, T. Correr o risco: ser homem numa profissão 'naturalmente' feminina. Congresso Português de Sociologia: Sociedades Contemporâneas: Reflexividade e Ação, Braga, Portugal, 2002.

SCHAFFRATH, M. D. A. S. Profissionalização do magistério feminino: uma história de emancipação e preconceitos. $23^{a}$ Reunião Anual da Anped, 2000.

SCHUELER, A. F. D. Representações da docência na imprensa pedagógica na corte imperial (1870-1889): o exemplo da instrução pública. Educação e Pesquisa, v. 31, n. 3, p. 379-390, set./dez. 2005.

SINISCALCO, M. T. A statistical profile of the teaching profession. Geneva: International Labour Office (ILO/OIT) - UNESCO, 2002.

STAMATTO, M. I. S. Um olhar na historia: a mulher na escola (Brasil: 1549 - 1910). II 
Congresso Brasileiro de História da Educação, Natal, 2002.

TANURI, L. M. História da formação de professores. Revista Brasileira de Educação, v. 14, p. 61-88, mai/jun/jul/ago. 2000.

TEODORO, A. Professores: que vencimentos? Lisboa: Edição do Autor, Distribuído por O Século, 1973.

VALLE, B. D. B. R. D. Salário do Professor: da posse à aposentadoria. I Congresso Brasileiro de História da Educaşão, Rio de Janeiro, 2000.

VIEIRA, J. D. Identidade expropriada: retrato do educador brasileiro. 2 ed. Brasília: CNTE, 2004.

WILLIAMS, C. Still a man's world: mens do women's work. Berkeley, CA: University of California Press, 1995.

\section{Notas}

1 RABELO, A. A figura masculina na docência do ensino primário: um "corpo estranho" no quotidiano das escolas públicas "primárias" do Rio de Janeiro-Brasil e Aveiro-Portugal. Tese (Doutorado em Ciências da Educação). Universidade de Aveiro, Aveiro, 2009.

2 Utilizaremos o termo "ensino primário" de acordo com a Classificação Internacional Tipo da Educação da Unesco (CITE 1, 1997, citada por Eurydice, 2001) e como tentativa de usar um termo compreensível no Brasil e em Portugal (pois este já foi utilizado em ambos os países) para designar o "1. " ciclo do Ensino Básico (1. CEB)" de Portugal e a "1." fase do Ensino Fundamental" do Brasil.

3 Entrevistamos seis professores e aplicamos inquéritos por questionário a uma amostra de 209 professores do ensino público, 60 do distrito de Aveiro (Portugal) e 149 do estado do Rio de Janeiro (Brasil).

4 Tenham até mesmo que aceitar ofertas para sobreviver (ARAÚJO, 2000; MÓNICA, 1978).

5 Inclusive, as políticas de João Franco, no final da Monarquia, pressupunham que os professores podiam viver com salários magros, cultivando batatas e couves nos quintais (1978).

6 Exceto nas Escolas Normais, onde as professoras continuaram recebendo salários menores do que os homens por muitos anos (ARAÚJO, 2000).

7 Neste ano, a educação é descentralizada e os salários passaram a não atrasar tanto como antes. Mas Carvalho também descreve que, apesar de a promessa dos aumentos de 1911 ter sido cumprida, o custo de vida subira bastante com a I Guerra Mundial, assim, a situação do professorado ficou tão má quanto anteriormente (1986).

8 As entrevistadas de Araújo (2000) não recordaram deste aumento salarial da década de 1920, que não teve muito impacto para estas professoras.

9 Como descreve também o nosso entrevistado Professor José (AV-PT), que fez a sua escolha profissional antes do 25 de abril de 1975, mas fez seu curso após a revolução.

10 Araújo (2000) mostra dados de que na época a única saída era buscar proventos suplementares noutras atividades, o que deteriorava a qualidade do ensino. 
11 Já existia a possibilidade de formação em nível de licenciatura para todos os professores, inclusive os primários e educadores de infância, embora também existisse a formação em nível de bacharel para esses docentes, a exigência de licenciatura para eles apenas acontece em 1997, com a Lei n. 115/97.

12 Seus colegas bancários ganhavam mais do que o dobro do seu salário. Seu colega que se tornou chefe de agência de correio, que tinha só a quarta classe, ganhava o dobro do seu salário.

13 Citando suas justificativas: "Consideram uma profissão com bom estatuto e boa remuneração na sociedade" (IPT15); "Acham que é uma profissão bem remunerada e que é bem vista na sociedade" (IPT51).

14 “Já não é aplicável um rendimento inferior” (IPT13); "Era uma área inferior até há algum tempo atrás” (IPT60).

15 "Só posso justificar o motivo dos pais, que preferiam que tivesse uma profissão mais bem remunerada" (IPT32).

16 Os autores mostram que, mesmo quando escolhem este curso como primeira opção, preferiam outros cursos (como psicologia), mas tinham consciência da não-acessibilidade destes a eles.

17 Nesta comparação, o Brasil tem a terceira pior remuneração dos professores primários.

18 A Cesta Básica Nacional Brasileira é uma lista de alimentos (que pode mudar um pouco, de acordo com a região), com suas respectivas quantidades, que seria suficiente para o sustento e o bem-estar de um trabalhador em idade adulta, contendo quantidades balanceadas de nutrientes, o Dieese faz uma pesquisa para saber o preço da mesma nas capitais brasileiras que serve até mesmo para estipular o salário mínimo. Fizemos tal simulação com os "preços ao menor de alguns artigos alimentícios" de Portugal divulgados no ILO - October Inquiry, contabilizando a mesma quantidade da cesta básica do Rio de Janeiro. Isso é só uma simulação, pois não foi utilizada a mesma técnica do Dieese e a cesta básica deve ser de acordo com os costumes alimentícios do local, que são diferentes em Portugal. Mas esta simulação dá uma ideia geral de como o poder aquisitivo do salário dos professores no Brasil e em Portugal é muito diferente.

19 Dados salariais provenientes do Censo do Magistério e do Ministério da Educação de Portugal.

20 O que poderia contradizer o que refere Jesus que tradicionalmente a docência não é tão bem-paga como outras profissões para as quais são necessárias as mesmas habilitações acadêmicas. E contradiz os dados encontrados por Teodoro, em 1973 (1973, p. 26-27), de que os professores recebiam salários menores do que eletricistas, serralheiros, cozinheiros.

21 Cabe destacar que, como referem Cruz et al. (1988), a falta de dados estatísticos (como a falta de valores para a remuneração média, inicial e final de cada categoria profissional) que também encontramos impede uma avaliação rigorosa e mais realista da evolução da situação dos professores frente a outras profissões. 
22 Como refere Jesus (2002): “uma maior valorização da educação escolar passa por um maior investimento na educação, traduzindo-se em salários [...]. Os aumentos salariais devem ocorrer sobretudo no início da carreira, nos salários de base, que é onde a diferença é proporcionalmente mais acentuada, comparativamente às grelhas salariais dos outros países da Europa".

23 As diferenças salariais entre professores e professoras, como já vimos, também eram justificadas pelo fato de a mulher não ensinar geometria, o que é demonstrado por Schaffrath (2000).

24 A autora encontra um artigo, em 1902, que descreve as dificuldades das "pobres" moças normalistas, no qual percebe-se, então, que o ordenado é baixo, mas desejado (1998).

25 Aposentar cinco anos antes das demais categorias profissionais (direito assegurado desde 1854), férias mais prolongadas, jornada de trabalho semanal reduzida e direito constitucional de ter dois cargos públicos (desde a constituição de 1934) (VALLE, 2000). 26 O professor pesquisado pela autora só recebeu, em 1984, pela função de especialista e só em 1988 os professores puderam ter sua formação acadêmica recompensada, apesar de a lei determinar isso em 1986.

27 Isso repercute na sociedade. Por exemplo, muitos entrevistados de Williams (1995, p. 174) culpam as mulheres pelos baixos salários ou a sociedade e a desvalorização da mulher (e do trabalho da mulher) pelos baixos salários das profissões.

28 Desprezando a carga horária de que um professor tem de dispor fora do seu horário letivo (como preparação de aulas, correção de trabalhos e provas, avaliação, reuniões, formação permanente, entre outras).

29 Destacamos que não dispomos dados de carga horária das outras profissões que analisamos no ano de 1991, mas, pelo que conhecemos da carga horária das profissões, podemos destacar que ganharia igual às/aos secretárias/os e ainda menos do que motoristas, agentes postais e mestres da construção civil.

30 Galbraith (1992, p. 246) também cita que homens envolvidos em ocupações sexoatípicas sugerem fatores como status e dinheiro como sendo parte de sua escolha profissional e satisfação.

31 Como Catani, Bueno, \& Sousa (2000, p. 61) demarcam, estes são “objetivos recorrentes no imaginário de algumas pessoas que nasceram e se criaram no interior e cuja infância foi vivida com dificuldades e limitações”.

32 Como os seguintes: "Muitos acreditam que a profissão ainda tem um certo status social e gostam. Outros questionam os baixos salários pagos e desaprovam minha escolha (IBR110)"; "Por ser uma profissão mal-remunerada, são de opinião que existem profissões mais rentáveis a meu alcance" (IBR118, IBR203, IBR92); "Baixa remuneração e pouco valor social” (IBR150; IBR170); “A profissão é má remunerada, assim sendo não deve ser exercida por homem" (IBR156); "Os amigos acham que ganho pouco (IBR168); "Na maioria dos casos não houve opinião expressa. Apenas a minha esposa acha a remuneração salarial ridícula, por esse motivo acha que devo mudar de profissão" (IBR175); "A insatisfação se dá em função do reconhecimento salarial” (IBR83, IBR88, 
IBR180, IBR189); "Meu pai é insatisfeito por causa do salário que temos" (IBR190); "Basicamente, o que causa a insatisfação é a visão que a sociedade tem do professor, não valorizando, em todos os aspectos, principalmente financeiro" (IBR192).

33 As políticas econômicas que visavam a não sobrecarregar o orçamento do Estado (mas que sobrecarregam em outras áreas), as políticas sociais e escolares que refletiam e davam continuidade às profundas desigualdades sociais existentes, a política cultural unilateral (destituindo aqueles que se opuseram), a política antilaica, que subordinava o ensino à religião.

34 Caso contrário o que tem acontecido é: os potenciais professores com maiores qualificações acadêmicas não escolhem a carreira docente; muitos professores abandonam ou têm a intenção de abandonar a profissão docente; muitos professores manifestam pouco envolvimento e empenhamento profissional.

35 Com o aumento do número de alunos e professores, com a pedagogização da sociedade, com a procura crescente de formação e com as novas tecnologias educativas.

36 Esteve (1992) apresenta doze indicadores básicos que resumem as mudanças recentes na educação: aumento das exigências em relação ao professor; inibição educativa de outros agentes de socialização; desenvolvimento de fontes de informação alternativas à escola; ruptura do consenso social sobre a educação; aumento das contradições no exercício da docênc-aluno; fragmentação do trabalho do professor.

Recebido: $05 / 05 / 09$

Aprovado: 20/08/09

Contato:

Rua Manuel B. Vasconcelos, $n^{\circ} 19,3^{\circ} \mathrm{AE}$,

CEP 3810-193

Aveiro - Portugal 